\title{
Density-dependent habitat selection: testing the theory with fitness data
}

\author{
DOUGLAS W. MORRIS \\ Department of Biology. Memorial University of Newfoundland, St John's. Newfoundland AIB 3X9, Canada
}

\begin{abstract}
Summary
According to density-dependent habitat selection theory, reproductive success should decline with increased density. Fitness should be similar between habitats if habitat selection follows an ideal frec distribution; fitness should be dissimilar between habitats if habitat selection is modified by territorial behavior. I tested these assumptions by examining a variety of fitness estimates obtained from white-footed mice living in nest boxes in forest, forest edge and fencerow habitats in southwestern Ontario. As expected, mean litter sizc declined with increased population density. Litter sizes, adult longevity and the proportion of adult animals in breeding condition were not significantly different among the three habitats. The success at recruiting at least one offspring to the adult population and the number of recruits per litter were much greater in the forest than in either of the other two habitats. Fitness was thus unequal among habitats and the results confirm both assumptions of density-dependent habitat selection theory for territorial white-footed mice.
\end{abstract}

Keywords: Density-dependence; fitness; habitat selection; ideal free distribution; life history; Ontario; rodent.

\section{Introduction}

The concept of density-dependent resource depression and its influence on habitat use is central to a variety of models in population biology (e.g. Rosenzweig, 1987a). Increased intraspecific density is assumed to increase the exploitation of limited resources and force individuals to occupy an ever-expanding range of habitats (Svärdson, 1949; Morisita, 1950 (cited in Rosenzweig, in press); Fretwell and Lucas, 1970; Rosenzweig, 1974, 1981). Habitat selection theory has been used to predict foraging behavior (e.g. Krebs and Davies, 1987) as well as the expected intensity of density-dependent population regulation and dispersal (Morris, 1987a, 1987b, 1988). Habitat heterogeneity modifies population dynamics and demography (Levin, 1976; Ostfeld et al., 1985; Adler, 1987) and the pattern of habitat occupation determines the segregation and structure of populations which influence rates of evolution (Christiansen, 1975; Holt, 1987). Habitat selection may function as a templet for the evolution of other ecological strategies (Southwood, 1977, 1988) and differential habitat selection plays a major role in the structure of ecological communities (Schoener, 1974; Rosenzweig, 1987b, in press).

Habitat use is influenced by morphological, physiological and behavioral adaptations which place an upper limit on habitat expansion, and is constrained by the density-dependent demands of similar consumers (Svärdson, 1949; Grant, 1975; Rosenzweig, 1979a, 1979b, 1981, 1986; Pimm and Rosenzweig, 1981). Other factors such as predation (Kotler, 1984; Price, 1984), mate selection (Rosenzweig, 1979b), and biogeographical and historical constraints no doubt also influence habitat use, but it is the effects of intra- and interspecific densities that have captured the imagination of evolutionary and behavioral ecologists. 
Density-dependent assumptions of habitat selection have been evaluated on a limited number of species. Most of these studies have yielded ambiguous results. The fundamental assumptions of the theory remain relatively untested.

\section{A brief review}

The theory of density-dependent habitat selection assumes that an individual should occupy only that habitat in which its evolutionary fitness is maximized. The actual pattern of density among habitats will depend upon which of two modes of habitat selection is appropriate to the species being investigated.

According to the ideal free distribution (Fretwell and Lucas, 1970), individuals are free to move among habitats and should assort themselves such that the expected fitness of individuals is constant across the habitat spectrum. Fitness is depressed as population density increases with the result that unoccupied habitats should be colonized whenever average fitness in those habitats is equal to that of the currently occupied habitat(s) (Fretwell and Lucas, 1970; Rosenzweig, 1974; Charnov, 1976). The ideal free distribution predicts that average fitness should be the same in all occupied habitats. Population density should reflect the qualitative and quantitative differences between habitats.

According to the ideal despotic (dominance) distribution, individuals are constrained in their habitat selection by the activities of dominant (usually territorial) individuals, and perceived fitness is devalued appropriately. Unlike ideal free assumptions, dominance results in unequal fitness rewards between quantitatively or qualitatively different habitats. In this model population density reflects not only the intrinsic differences between habitats, but also the additional effect of dominance behavior.

Most tests of habitat selection theory have been incomplete and often inconclusive. Behavioral ecologists have attempted a series of tests usually using traits associated with foraging as surrogates of evolutionary fitness (e.g. Milinski, 1979, 1984; Harper, 1982; and references in Parker and Sutherland, 1986). The relationship of the behavioral surrogate to fitness has seldom been empirically demonstrated. Population ecologists have devised ingenious indirect tests based on distributional patterns (Fretwell, 1972; Fraser and Sise, 1980; Emlen, 1985; Rosenzweig and Abramsky, 1985; Morris, 1987a, 1987b) but the underlying assumptions have rarely been evaluated (Morris, 1987a used demographic estimates of fitness), and the patterns could have other causes. Community ecologists have begun indirect tests which appear to confirm the theory (Rosenzweig et al., 1984; Pimm et al., 1985; Rosenzweig, 1986) but again, the fundamental assumptions have not been evaluated.

Two famous studies have attempted to test the theory directly. Krebs (1971) removed resident great tits from woodland and observed the recolonization of their territories by younger birds from nearby hedgerows. Krebs' own data and a survey of nest records from other hedgerows revealed that the hedgerow residents had lower fitness than those in the woods. Hedgerow birds also tended to be younger than those in woods, and some of the apparent habitat effect of fitness was due to age differences.

Whitham $(1978,1980)$ recorded the production of offspring by aphid stem mothers living on poplar leaves of different productivity. The average number of offspring per individual was constant across leaves of different size classes. Within leaves, offspring production was unequal. Females appeared to compete for the 'best' oviposition sites, and by inference, for leaves of different quality. Gall formation in poplars is successful only during a limited time-span before leaves are unfurled, and the pattern of distribution and abundance of aphid stem mothers may be a necessary consequence of leaf phenology instead of habitat selection (Rhomberg, 1984). 
In this paper I attempt an unambiguous test of density-dependent habitat selection theory. First, I evaluate whether fitness within a habitat declines with increased population density. Second, I compare several estimates of reproductive success among habitats to rigorously test for fitness differences.

\section{Methods}

Small wooden nest boxes (internal dimensions $14 \times 15 \times 22 \mathrm{~cm}$ with one $2.5 \mathrm{~cm}$ entrance hole) were placed within second-growth deciduous forest, in forest margins and along overgrown fencerows on a 40 ha field site in an agricultural landscape between lakes Erie and St Clair in southwestern Ontario $\left(42^{\circ} 10^{\prime} \mathrm{N}, 82^{\circ} 30^{\prime} \mathrm{W}\right)$. Boxes were placed at suitable sites within $10 \mathrm{~m}$ of permanent stations located at $30 \mathrm{~m}$ intervals. These boxes were readily colonized by white-footed mice (Peromyscus leucopus). The life histories of these mice were monitored in the boxes during the spring and autumn from 1981 to 1986 . In 1982, many of the animals died from an unidentified disease and the boxes were not checked in the autumn of that year.

The dominant trees, both in the woods and fencerows, are white and red oak (Quercus alba, Q. rubra). Other common trees include elms (Ulmus americana, U. rubra), white ash (Fraxinus americana), hawthorn (Crataegus spp.) and hickory (Carya spp.). A thick understory composed mainly of saplings, red-osier dogwood (Cornus stolonifera), brambles (Rubus spp.) and prickly ash (Zanthoxylum americanum) is present in all locations. The forest edge and fencerows define a sharp ecotone between forest vegetation and cultivated farmland. Fencerow widths range from 4 to $8 \mathrm{~m}$.

All nest boxes were examined in clear weather during daylight hours three times each spring (April, May, June) and twice each autumn (September, October). I was unable to examine all of the boxes in one day, and weather conditions and other constraints often made it necessary to extend sampling over several days. At the beginning of the study 36 boxes were located in the fencerows and 28 in the forest edge; 15 boxes were placed in the forest in early June 1981. In autumn 1984, an additional four boxes were added to a previously unsampled segment of the fencerow habitat. To classify as a forest box, the permanent station must have been located at least $30 \mathrm{~m}$ from the nearest non-forest habitat. All edge boxes were located within $10 \mathrm{~m}$ of an agricultural field. For the analyses that follow, I contrasted fitness estimates between the two fencerow habitats taken together, the woodlot (forest) and forest edge.

During each examination all mice over one week old were removed from the boxes, aged, sexed, measured (body length and tail length), and individually marked with metal ear tags. The age of immature and juvenile mice was estimated on the basis of literature reports of developmental stages (Layne, 1968), and all adults and most young mice were weighed. All animals were classified as reproductive (testes descended for males, perforate vagina, lactation and/or pregnancy for females) or not. Soiled nests were replaced with fresh mattress stuffing, the mice placed back in the box, and the box returned to its original position. Damaged boxes were replaced with new ones.

Litters were included in the analyses only if: (a) similar aged immature (eyes closed) or not fully coordinated juvenile mice were observed nursing an adult female or were in the same box with only one lactating female (the majority of cases), or (b) immature mice at the same stage of development were found alone in a nest box. If more than one litter was found in the same box each was included in the data set (c) only if I could be reasonably certain of sib relationships by developmental differences. Fully coordinated juvenile mice were not counted as litters, even if in the presence of a lactating female, because they may have been close to weaning. Recruitment of litter-mates was based on the capture in any nest box of adult mice originally marked in litters 
satisfying criterion (a), (b) or (c). This is a minimum estimate because sampling was restricted to spring and autumn reproductive seasons and excludes animals which may not have returned to the nest boxes but, nevertheless, may have successfully reproduced elsewhere.

The woodlot nest box array was overlain by a live-trap grid with station intervals at $15 \mathrm{~m}$. Every station was live-trapped twice each spring and autumn using six trap rotations where single Longworth live-traps were set at all stations on every third trap-line. Traps were placed within $1 \mathrm{~m}$ of each station. Each trap contained mattress stuffing as bedding and was baited with a peanut butter-flour mixture, oatmeal, and a slice of potato. Traps were set in the evening and collected at first light the following day. All soiled traps were thoroughly washed with detergent, rinsed in clear water, and dried before being re-set. All captured rodents were individually marked with metal ear tags. Age, sex, reproductive condition, and body measurements were recorded, and the animals released. Seasonal population densities in the woodlot were estimated as the minimum number of adult animals known to be alive from the accumulated trap records of that season.

I compared five estimates of reproductive success among habitats: litter size, litter success, recruitment rate, adult longevity and the proportion of breeding adults. I also analyzed for differences in recapture success and movement between habitats. It would be interesting to include additional fitness estimates such as age at first reproduction, but currently my most reliable sample sizes are for the five variables analyzed here.

Recruitment rate was evaluated by goodness-of-fit tests using G statistics with Williams' correction for small samples (Sokal and Rohlf, 1981). Recapture success and movement among habitats were evaluated by $\mathrm{G}$ tests of independence. Inter-habitat comparisons of litter size, litter success, adult longevity and breeding status were corrected for seasonal and annual effects by hierarchical log-linear analysis (SPSS ${ }^{x}$, Norušis, 1985). This procedure generates the most parsimonious statistical model capable of 'explaining' the effects of the influence of the different factors on fitness (Bishop et al., 1975). The likelihood-ratio chi-square, like sums-of-squares in analysis of variance, was partitioned into additive effects (Norušis, 1985). Partíal chi-squares were calculated to evaluate the effects of individual factors and their interactions while 'controlling' for the effects of other factors and interactions. Log-linear models evaluate whether or not a particular categorical variable is independent of the effects of other variables (habitat and temporal variation in this paper). The hierarchical log-linear analyses I use here can thus be thought of as factorial non-parametric analyses of variance. Interactions between habitat and the fitness estimates are particularly important because these specify how habitat affects reproductive success. Statistical significance corresponded to type I error rates of $5 \%$ or less.

To create categorical variables for the log-linear analyses I partitioned litter sizes into two classes of equal frequency, large $(>4,141$ litters) and small ( $<5,140$ litters). Litters were similarly partitioned into successful (recruited one or more offspring to the adult nest box population) and unsuccessful (recruited none) classes. Adult longevity was estimated from the maximum known duration on my study area of adult animals originally marked as sub-adults, juveniles or immatures during 1983-5 (the ages of these animals can be back-calculated to estimate birth date). Adult longevity calculated in this way is a minimum estimate because sampling was biannual during nest box observations and because death and emigration could not be differentiated for most animals. The median longevity of these animals was 171 days, so I partitioned the data into short-lived ( $<172$ days) and long-lived ( $>171$ days) survivorship classes. The analysis of longevity, like the analysis of litter size, is effectively a factorial median test.

The most general log-linear model could not always be analyzed because some cells had low expected values. Whenever reasonable, this problem was overcome by a reduced model analyzing a subset of factors. If there were no significant interactions in the reduced model, data 
were combined for subsequent analyses. All log-linear analyses were conducted such that no expected cell frequencies had values of less than 1.0. In some cases the number of cells with expected frequencies less than 5.0 exceeded the rule-of-thumb that no more than $20 \%$ of the total number of cells should have expected values this low. Whenever this occurred either the fitness $x$ habitat interaction was non-significant, or the likelihood-ratio chi-square of interest was highly statistically significant and able to compensate for any bias in type I error rates.

\section{Results}

Timing of reproduction

White-footed mouse reproduction in southern Ontario is concentrated during the spring and autumn. In 1981, for example, when I was able to check boxes each month from April to December (Morris, 1986), I recorded 45 litters in April, May and June; 26 in September and October, and only 8 litters during July and August. Fitness estimates calculated from spring and autumn litters should thus be representative of reproductive success by this species at my study site.

\section{Population density}

There was a marked biannual pattern with total population density estimates varying between a low of eight adults (spring 1986) to a high of 75 (autumn 1983, Fig. 1). Spring populations were always lower than the subsequent autumn density, but not necessarily lower than all autumn density estimates. These data are consistent with a variety of other demographic studies of Peromyscus (e.g. Terman, 1968; Batzli, 1977; Fairbairn, 1977; Hansen and Batzli, 1978; Yahner,

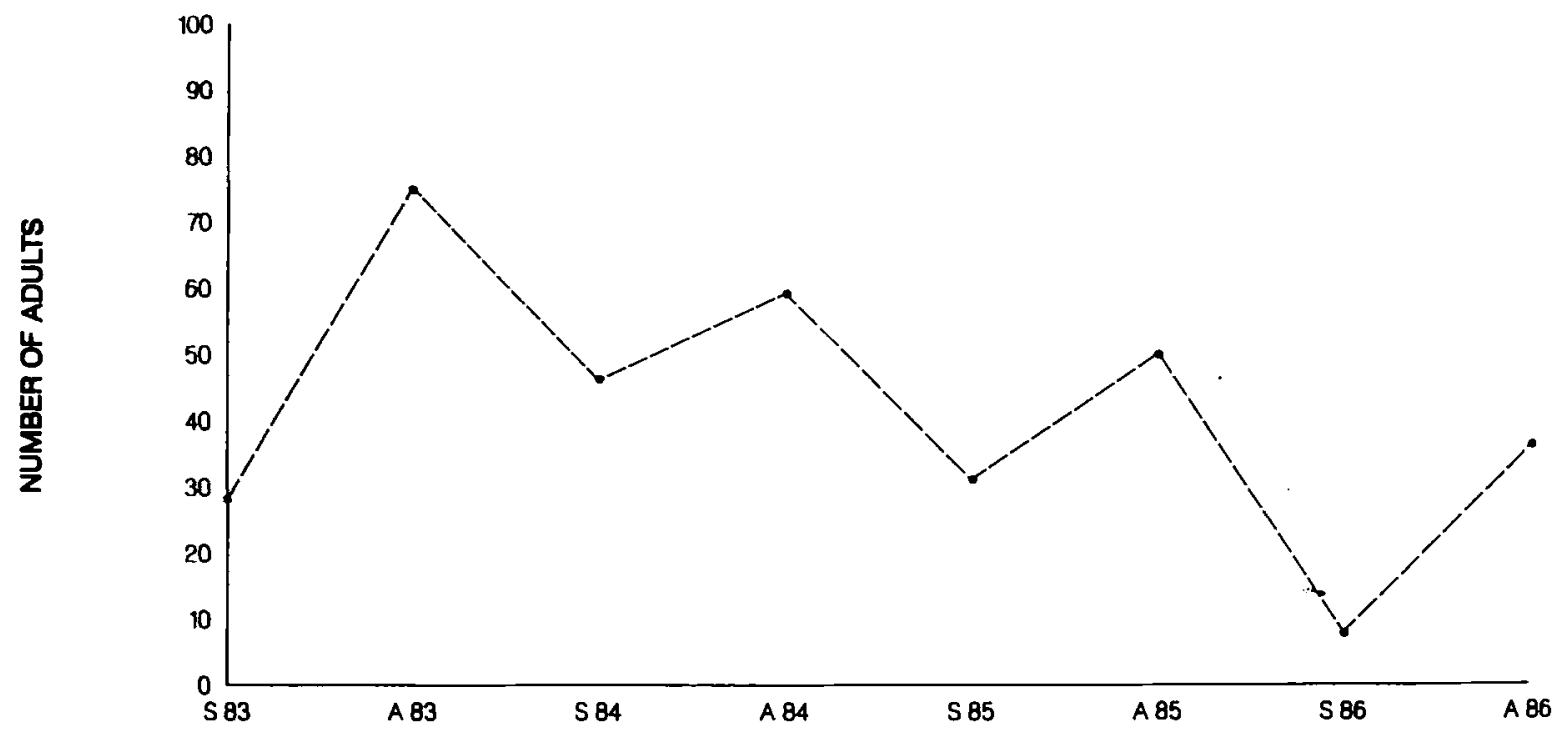

SEASON AND YEAR

Figure 1. Spring (S) and autumn (A) population dynamics for the period 1983-6 of Peromyscus leucopus inhabiting a second-growth deciduous forest in southwestern Ontario. 
1983). The correspondence between these studies demonstrates that my density estimates captured the essence of population dynamics by $P$. leucopus, and that my estimates can be used to explore the density-dependence of habitat selection in the forest habitat.

\section{Litter size and population density}

I evaluated the assumption that reproductive success declines with increased density by plotting the appropriate means of 114 spring and autumn litters in the forest and edge boxes (these were not statistically different, see next section) against my independent trap estimate of population density in the forest. Litter size declined consistently with increased population density $(r=$ $-0.85, p<0.01$, Fig. 2). One reason for this result may appear to be a trend toward the production of larger litters in the spring when population density was low, and smaller litters in the autumn when population density was high. This interpretation may yet prove to be true, but two arguments suggest that it is likely not to influence the interpretation of density-dependent reduction in litter size. First, litter-size distributions were not significantly different between seasons (see next section). Second, Fig. 2 shows a consistent negative trend in litter size with increased population density. I would like to supplement this test with a similar plot of successful recruitment with density, but because I have adequate recruitment samples only for spring-born litters, this test awaits the accumulation of more data.

Figure 2. Mean litter size of Peromyscus leucopus declined with increased density. Filled circles represent spring data, open circles represent autumn data. The number of litters used for each estimate is included in parentheses.

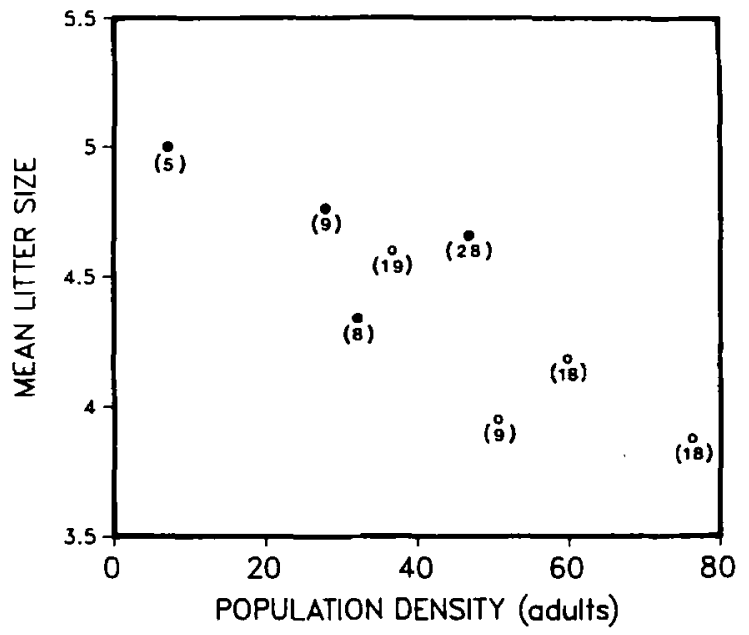

\section{Litter size and habitat}

Habitat-related differences in litter size were tested by log-linear analysis of 281 litters recorded in 1981 and 1983-6. I controlled annual effects in a hierarchical analysis. A significant interaction between litter size and any combination of the other two main effects (habitat and year) would demonstrate that litter size depended upon those effects. The analysis was highly significant (Table 1) with a significant two-way interaction between habitat and year (the number of litters observed depended upon which habitat-year combinations were compared).

Litter size did not vary significantly with habitat though there was a trend $(p=0.075)$ toward larger litters in the fencerow habitat (Fig. 3). The significant year effect means that more litterswere observed in some years than in others; the same was true for habitat. I repeated the analysis 
Table 1. Hierarchical log-linear analysis evaluating habitat and annual variation in litter size (281 litters). No expected values $<2 ; 4$ of 30 cells had expected values $<5$.

\begin{tabular}{lcrc}
\hline Source & $x^{2 *}$ & $\mathrm{df}$ & $p$ \\
\hline 1-Way effects & 41.5 & 7 & $<0.0001$ \\
2-Way interactions & 31.6 & 14 & $<0.005$ \\
3-Way interaction & 12.3 & 8 & 0.14 \\
Total & 85.4 & 29 & $<0.0001$ \\
& & & \\
Litter $\times$ Habitat & 5.17 & 2 & 0.075 \\
Litter $\times$ Year & 8.13 & 4 & 0.087 \\
Habitat $\times$ Year & 18.94 & 8 & 0.015 \\
& & & \\
Litter & 0.004 & 1 & 0.95 \\
Habitat & 30.05 & 2 & $<0.0001$ \\
Year & 11.46 & 4 & 0.022 \\
\hline
\end{tabular}

*Overall analysis evaluated by likelihood-ratio chi-square; specific interaction terms and main effects evaluated by partial association tests.

by evaluating habitat and seasonal effects on litter size (Table 2). None of the two-way interactions was statistically significant. Seasonality had no apparent effect on either litter size or its possible relationship with habitat.

Fitness, nevertheless, could be different between habitats if either the proportion of litters recruiting any offspring into the breeding population (so-called litter success) or the number of

FENCEROW

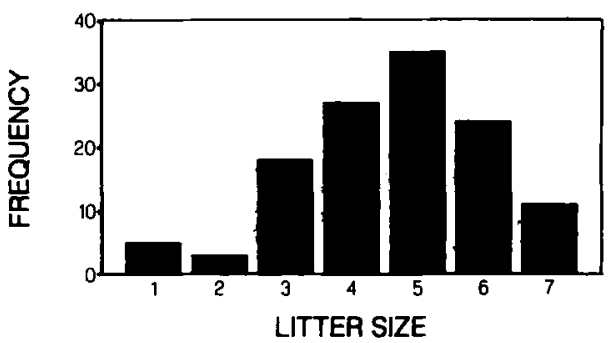

EDGE

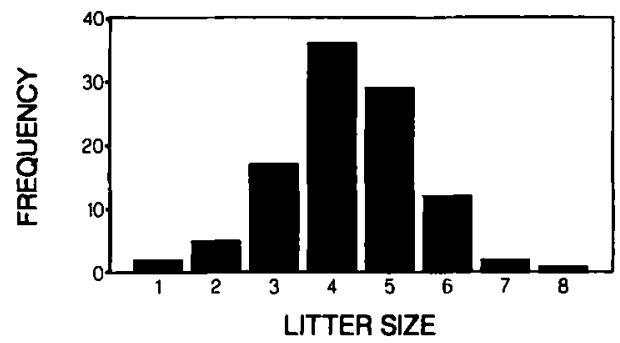

\section{FOREST}

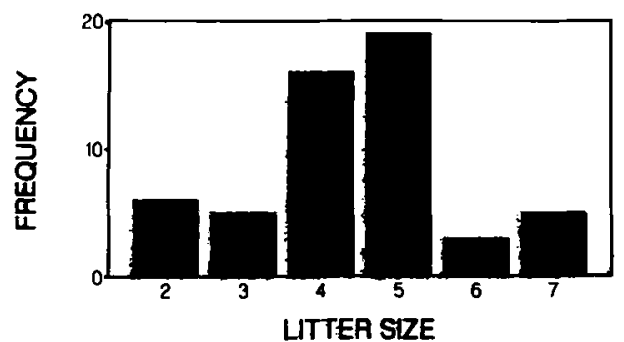

Figure 3. Litter sizes of Peromyscus leucopus were similar in fencerow, edge and forest habitats. 
Table 2. Hierarchical log-linear analysis evaluating habitat and seasonal variation in litter size (281 litters). No expected values $<5$.

\begin{tabular}{lrrc}
\hline Source & \multicolumn{1}{c}{$\chi^{2 *}$} & $\mathrm{df}$ & $p$ \\
\hline 1-Way effects & 30.3 & 4 & $<0.0001$ \\
2-Way interactions & 5.6 & 5 & 0.34 \\
3-Way interaction & 2.0 & 2 & 0.36 \\
Total & 37.9 & 11 & $<0.0001$ \\
\hline
\end{tabular}

${ }^{*}$ Likelihood-ratio chi-square.

young recruited from successful litters (recruitment rate) vary with habitat. I evaluated both mechanisms.

\section{Litter success}

The log-linear analysis (212 litters) contrasting habitat and seasonal effects on litter success was highly significant (Table 3). Litter success was much greater in spring than in autumn (40 of 105 spring litters were successful; 9 of 107 autumn litters were successful, $p<0.0001$ ), and also much greater in the forest than in either of the other two habitats ( 18 of 45 forest litters were successful compared with 13 of 73 for the edge and 18 of 94 for the fencerow, $p=0.007$ ).

Table 3. Hierarchical log-linear analysis evaluating habitat and seasonal variation in litter success (212 litters). No expected values $<2 ; 3$ of 12 cells had expected values $<5$.

\begin{tabular}{lrcc}
\hline Source & \multicolumn{1}{c}{$\chi^{2 *}$} & $\mathrm{df}$ & $p$ \\
\hline 1-Way effects & 82.4 & 4 & $<0.0001$ \\
2-Way interactions & 41.7 & 5 & $<0.0001$ \\
3-Way interaction & 3.9 & 2 & 0.14 \\
Total & 128.0 & 11 & $<0.0001$ \\
Success $\times$ Habitat & 10.02 & 2 & 0.007 \\
Success $\times$ Season & 29.47 & 1 & $<0.0001$ \\
Habitat $\times$ Season & 5.33 & 2 & 0.07 \\
Success & & & \\
Habitat & 64.66 & 1 & $<0.0001$ \\
Season & 17.76 & 2 & $<0.0001$ \\
\hline
\end{tabular}

*Overall analysis evaluated by likelihood-ratio chi-square; specific interaction terms and main effects evaluated by partial association tests.

\section{Recruitment rate}

I tested for habitat differences in recruitment by comparing the actual number of recruits relative to the expected number assuming an equal chance of recruitment per litter in all habitats. The expected number of recruits was generated by multiplying the number of litters with individually identified young in a habitat by the empirical recruitment rate for all habitats combined. To 
Table 4. Spring recruitment rates among fencerow, edge and forest habitats. Expected values were generated by multiplying the number of litters in each habitat by the overall number of recruits per litter (0.5619) $\left(\mathrm{G}_{\text {Williams' }}=14.37, p<0.001\right)$.

\begin{tabular}{lllll}
\hline Habitat & $\begin{array}{l}\text { Number of } \\
\text { litters }\end{array}$ & $\begin{array}{l}\text { Recruits } \\
\text { (observed) }\end{array}$ & $\begin{array}{l}\text { Recruits } \\
\text { (expected) }\end{array}$ & $\begin{array}{l}\text { Recruits } \\
\text { litter }\end{array}$ \\
\hline Fencerow & 40 & 15 & 22.5 & 0.38 \\
Edge & 42 & 18 & 23.6 & 0.43 \\
Forest & 23 & 26 & 12.9 & 1.13 \\
\hline
\end{tabular}

standardize for the significant seasonal differences, this analysis included only the 105 spring-born litters. The forest habitat had a far greater recruitment rate per litter than either of the other two habitats (Table 4, single classification goodness-of-fit test, $G$ with William's correction $=14.37$, $p<0.001)$.

\section{Recapture success}

It could be argued that the recruitment data simply reflect a higher probability of capture in the forest 'grid' of nest boxes than in the edge and fencerow nest box 'transects'. If this is true it should be reflected in differences in the recapture success of animals among the three habitats. Using only nest box data, I calculated the number of animals available for recapture at time $(t+1)$ as the number that were known to be alive during nest box checks at times $(t)$ and $(t+i)$ where $i>1$. I then compared the number available for recapture that were not captured, with the number of these animals actually recaptured during time $(t+1)$. Recapture success was $52.8 \%$; there were no significant differences in recapture success among habitats (Table 5,2 23 test of independence, $\mathrm{G}=1.66,0.1<p<0.5$ ).

Table 5. Recapture success of white-footed mice living in three habitats in southwestern Ontario $(\mathrm{G}=1.66,0.1<p<0.5)$.

\begin{tabular}{llll}
\hline Capture status & \multicolumn{3}{c}{ Observations per habitat } \\
\cline { 2 - 4 } & Fencerow & Edge & Forest \\
\hline Known alive but not & & 43 & 39 \\
$\quad$ recaptured & 26 & 46 & 37 \\
Recaptured & 38 & 46 \\
\hline
\end{tabular}

The litter success and recruitment data suggest that the reproductive success of mice living in the forest habitat may exceed that of mice in the edge and fencerow. This assumes that parents in the three habitats produce more or less the same number of litters during their respective lifetimes. Ultimately, I would like to test this assumption with detailed data on reproduction of individual females throughout their entire lifetimes. Such data would need to be corrected for seasonal and yearly differences and the accumulation of reliable sample sizes for such an analysis is logistically demanding. I can, nevertheless, test the assumption indirectly using demographic data. The expected production of litters by females in a given habitat will be determined by how long individual females can be expected to live, and by the proportion of those females that are in reproductive condition during each reproductive season. I evaluated both of these mechanisms by log-linear analysis. 


\section{Adult longevity}

The log-linear analysis of 78 animals first captured as pre-adults during 1983-5 was marginally significant $\left(\chi^{2}=18.02, p=0.08\right)$ but habitat had no effect on median longevity (Table 6). Both sexes had similar longevities (Morris, unpubl.). The maximum known lifetimes were 516 and 514 days for two spring-born forest males. No animals were known to survive more than one winter.

Table 6. Hicrarchical log-linear analysis cvaluating habitat and scasonal effects on adult longevity (78 animals). No cxpected values $<3 ; 3$ of 12 cells had expected values $<5$.

\begin{tabular}{lccl}
\hline Source & $x^{2 *}$ & df & $p$ \\
\hline 1-Way effects & 5.5 & 4 & 0.24 \\
2-Way interactions & 12.4 & 5 & 0.029 \\
3-Way interaction & 0.09 & 2 & 0.95 \\
Total & 17.99 & 11 & 0.08 \\
Longevity $\times$ Habitat & 4.59 & 2 & 0.1 \\
Longevity $\times$ Season & 7.39 & 1 & 0.007 \\
Habitat $\times$ Season & 1.70 & 2 & 0.43 \\
Longevity & 0.00 & 1 & 1.0 \\
Habitat & 0.31 & 2 & 0.86 \\
Season & 5.19 & 1 & 0.02 \\
\hline
\end{tabular}

*Overall analysis evaluated by likelihood-ratio chi-square; specific interaction terms and main effects evaluated by partial association tests.

\section{Reproductive condition}

The log-linear analysis (614 captures) evaluating habitat, seasonal and annual effects on reproductive condition was highly significant $\left(\chi^{2}=389.9, p<0.0001\right)$ and included highly significant three-way and two-way interactions (Morris, unpubl.). Reproductive condition depended upon habitat (partial $\chi^{2}=7.04, p=0.03$ ) but also depended upon seasonal and annual effects. An analysis comparing habitat and sexual differences in reproductive condition was also highly significant $\left(x^{2}=448.5, p<0.0001\right)$ and demonstrated that more males than females were recorded in reproductive condition $\left(91.8 \% \vee 79.2 \%\right.$ respectively, partial $\left.\chi^{2}=13.07, p<0.001\right)$. Reproductive condition did not depend upon $\mathrm{h}$ - bitat in this analysis (partial $\chi^{2}=1.8, p=0.4$ ).

Analysis of the seasonal variation showed that relatively more animals were in reproductive condition in the spring than in the autumn. Litter success during spring was substantially greater than during autumn, so I repeated the log-linear analysis using only adult animals captured during the spring. The log-linear analysis ( 315 captures) showed significant two-way interactions (Table 7) but there was no residual dependence of reproductive condition on habitat.

\section{One source of mortality}

Fencerows seem to serve as migration and foraging corridors for a variety of native and domestic carnivores. Virtually all records of mustelid activity at nest boxes (based on scats and/or mouse cadavers) were in the fencerows ( 31 of 32 observations, the other was a forest edge box), and the two cases of severe damage to boxes by feral or native canids were also in fencerows. These mortality vectors should have a disproportionate effect on young animals because successfully 
Table 7. Hierarchical log-linear analysis evaluating habitat and annual variation in reproductive condition (315 spring captures). No expected values $<1 ; 8$ of 18 cells had expected values $<5$.

\begin{tabular}{lrrc}
\hline Source & \multicolumn{1}{c}{$\chi^{2 *}$} & df & \multicolumn{1}{c}{$p$} \\
\hline 1-Way effects & 257.2 & 5 & $<0.0001$ \\
2-Way interactions & 16.2 & 8 & 0.04 \\
3-Way interaction & 1.7 & 4 & 0.79 \\
Total & 275.1 & 17 & $<0.0001$ \\
& & & \\
Reproduction $\times$ Habitat & 0.46 & 2 & 0.80 \\
Reproduction $\times$ Year & 5.16 & 2 & 0.08 \\
Habitat $\times$ Year & 11.25 & 4 & 0.02 \\
Reproduction & 234.09 & 1 & $<0.0001$ \\
Habitat & 14.69 & 2 & 0.0006 \\
Year & 8.43 & 2 & 0.01 \\
\hline
\end{tabular}

${ }^{*}$ Overall analysis cvaluated by likelihood-ratio chi-square; specific interaction terms and main effects evaluated by partial association tests.

recruited animals showed no differences in adult longevity between habitats. This hypothesis awaits experimental confirmation.

\section{Movement patterns}

I determined the movement of animals between habitats by counting the number of animals 20 days of age or older that were recorded in nest boxes in one habitat and subsequently recorded in a different habitat (Table 8). I analyzed these data by contrasting the number of animals moving into each habitat with the number moving away from that habitat. There was no preferential movement toward any one habitat (test of independence, $\mathrm{G}=0.84,0.5<p<0.9$ ).

Table 8. Movement of white-footed mice among three habitats in southwestern Ontario.

\begin{tabular}{lllc}
\hline Habitat of first* capture & \multicolumn{3}{c}{ Habitat of subsequent capture } \\
\cline { 2 - 4 } & Fencerow & Edgc & Forest \\
\hline Fencerow & - & 10 & 3 \\
Edge & 15 & - & 21 \\
Forest & 4 & 21 & - \\
\hline
\end{tabular}

*Some animals changed habitats more than once.

\section{Discussion}

To summarize, naturally occurring litter sizes of white-footed mice declined with increased population density. Mice in the three habitats produced similar-sized litters (though there was a 
Table 9. Summary of differences and similarities in the life history of Peromyscus leucopus living in three habitats in southwestern Ontario.

\begin{tabular}{ll}
\hline Character & Effect of habitat \\
\hline Litter size & (Fencerow $=$ Edge $=$ Forest) \\
Litter success & (Fencerow $=$ Edge) $<$ Forest \\
Spring recruitment per litter & (Fencerow $=$ Edge) $<$ Forest \\
Adult longevity & (Fencerow $=$ Edge $=$ Forest) \\
Proportion of adults breeding & (Fencerow $=$ Edge $=$ Forest) \\
Weasel predation & Fencerow $>$ (Edge $=$ Forest) \\
Movement & No habitat preference \\
Overall fitness & (Fencerow $=$ Edge) $<$ Forest \\
\hline
\end{tabular}

trend toward larger litters in the fencerows) and experienced similar adult longevity (Table 9). Litter success and recruitment rate were much greater in the forest than in the other two habitats. During the spring reproductive season, which yielded the majority of recruits, there was no difference between habitats in the proportion of reproductive adults. Predation seemed to be more intense in the fencerows than in the other habitats. Combining these results, mice living in the forest appeared to have a higher expectation of reproductive success than mice living in fencerows or forest edge. This implies that the forest should be recognized by white-footed mice as a superior habitat relative to the fencerow and edge which should be perceived as being more or less equal.

Habitat selection by white-footed mice appears to be density-dependent (litter size declined with density) and is consistent with the predictions of a dominance distribution (average fitness greater in one habitat than in another). This conclusion is bolstered by the lack of directional movement toward the high-fitness forest habitat and is further supported by the observation that female white-footed mice are territorial during the breeding season (Burt, 1940; Nicholson, 1941; Stickel, 1968; Metzgar, 1971; Rowley and Christian, 1976). The empirical data and the natural history of white-footed mice are thus in complete agreement with the theory of densitydependent habitat selection.

I confess to being skeptical about the convincing evidence in favor of density-dependent feedback on litter size. I originally suspected that populations of short-lived animals as prolific as these white-footed mice would be easily able to track environmental variation in resource levels and be more or less regulated toward equilibrium with carrying capacity. This would, in turn, imply more or less constant levels of resources per individual female, and litter sizes too should be relatively insensitive to changes in population density. That hypothesis now appears to have been naive, either because seasonal variation in population density acts as a time-lag which destroys the synchrony between population dynamics and resource availability, or more probably, because carrying capacity changes more rapidly than the ability of even rodents to track those changes. If this latter interpretation is true for species with the recruitment potential of small rodents, it is likely also to be true for most species. Complex population dynamics may have more to do with changes in resources than they do with the innate instability of time-lag dynamics of populations with rapid response times (e.g. May, 1981). The more important message is, that if habitat selection by animals like these is density-dependent, it is also likely to be density-dependent for any other species with lower potential for recruitment.

Ecologists considering following my example of fitness tests of habitat selection theory should be wary of an insidious bias that tips the statistical scale in favor of a dominance distribution. Our 
statistical methodologies have been designed to show whether two or more samples are likely to differ from one another (e.g. Toft and Shea, 1983). We cannot use complementary reasoning to give probabilistic statements about two or more samples being the same unless we know a priori how small a difference evolution may recognize as 'significant'. An analysis similar to mine that found no differences in fitness between habitats would imply assumptions consistent with an ideal free distribution but could not be legitimately interpreted as a test that fitness is the same in each habitat.

Two points need to be re-emphasized. First, the results of a variety of tests support the basic assumptions and predictions of the theory of density-dependent habitat selection. or at least. those results can be effectively interpreted in the light of the theory. Second, the work I report here shows how easily evolutionary ecologists and the organisms they study can be deceived if they are unable to evaluate all the components of reproductive success. Had I restricted my analyses to litter-size data alone I would have concluded that reproductive performance was density-dependent and that fitness was more or less equal in the three habitats. I would have made the same conclusion had I also looked at the reproductive condition and longevity of adults. Only by considering as many components of reproductive success as possible was I able to sketch a reasonable outline of density-dependent habitat selection by white-footed mice.

\section{Acknowledgements}

I thank Kelly Morris whose friendship and field and computer assistance were essential to the successful completion of this work. This paper was improved by the candid suggestions of anonymous referees. I also thank John Enright for frequent field assistance. Paul Anderson for providing nest box lumber. Monarch Mattress Company for free and copious nesting material. Morridell Farms Ltd for access to research sites, Jack Enright for helping to exclude predators from my Longworth live-traps and Memorial University Computing Services for unlimited computing. The 1981 field work was completed while I held a NSERC postdoctoral fellowship at The University of Western Ontario. The continued support of Canada's Natural Sciences and Engineering Research Council (Grant A0411) is gratefully appreciated.

\section{References}

Adler. G. H. (1987) Influcnce of habitat structure on demography of two rodent species in eastern Massachusetts. Canad. J. Zool. 65, 903-12.

Batzli, G. O. (1977) Population dynamics of the white-footed mouse in floodplain and upland forests. Amer. Midl. Narur. 97, 18-32.

Bishop. Y. M. M., Feinberg. S. E. and Holland, P. W. (1975) Discrete Multivariate Analysis: Theory and Practice, MIT Press, Cambridge, MA, USA.

Burt, W. H. (1940) Territorial behavior and populations of some small mammals in southern Michigan. Misc. Publ. Mus. Zool. Univ. Mich. 45, 1-58.

Charnov, E. L. (1976) Optimal foraging: the marginal value theorem. Theor. Pop. Biol. 9, 129-36.

Christiansen, F. B. (1975) Hard and soft selection in a subdivided population. Amer. Natur. 109. $11-16$.

Emlen, J. M. (1985) The assessment of frequency- and density-dependent influences on fitness in natural populations. Amer. Natur. 125, 507-20.

Fairbairn, D. J. (1977) The spring decline in deer mice: death or dispersal? Canad. J. Zool. 55, $84-92$.

Fraser, D. F. and Sise, T. E. (1980) Observations on stream minnows in a patchy environment: a test of a theory of habitat distribution. Ecology 61, 790-7.

Fretwell, S. D. (1972) Populations in a Seasonal Environment, Princeton University Press, Princeton, N\}, USA. 
Fretwell, S. D. and Lucas, H. L. Jr (1970) On territorial behavior and other factors influencing habitat distribution in birds. I. Theoretical development. Acta Bioth. 19, 16-36.

Grant, P. R. (1975) Population performance of Microtus pennsylvanicus confined to woodland habitat, and a model of habitat occupancy. Canad. J. Zool. 53, 1447-65.

Hansen, L. P. and Batzli, G. O. (1978) The influence of food availability on the white-footed mouse: populations in isolated woodlots. Canad. J. Zool. 56, 2530-41.

Harper, D. G. C. (1982) Competitive foraging in mallards: 'ideal free' ducks. Anim. Behav. 30, 575-84.

Holt. R. D. (1987) Population dynamics and evolutionary processes: the manifold roles of habitat selection. Evol. Ecol. 1, 331-47.

Kotler, B. P. (1984) Risk of predation and the structure of desert rodent communities. Ecology 65, 689-701.

Krebs, J. R. (1971) Territory and breeding density in the great tit, Parus major L. Ecology 52, 2-22.

Krebs, J. R. and Davies, N. B. (1987) An Introduction to Behavioural Ecology, 2nd edn, Sinauer Associates. Sunderland. MA. USA.

Layne, J. N. (1968) Ontogeny. In Biology of Peromyscus (Rodentia) (ed. J. A. King). American Society of Mammalogists. Stillwater, OK, USA, pp. 148-253.

Levin, S. A. (1976) Population dynamic models in heterogeneous environments. Ann. Rev. Ecol. Syst. 7, 287-310.

May, R. M. (1981) Models for single populations. Theoretical Ecology: Principles and Applications, 2nd edn (ed. R. M. May), Sinauer Associates, Sunderland, MA, USA, pp. 5-29.

Metzgar, L. H. (1971) Behavioral population regulation in the woodmouse. Peromyscus leucopus. Amer. Midl. Natur. 86, $434+7$.

Milinski. M. (1979) An evolutionary stable feeding strategy in sticklebacks. Zeitsch. Tierpsych. 51, 36-40.

Milinski, M. (1984) Competitive resource sharing: an experimental test of a learning rule of ESSs. Anim. Behav. 32, $233-42$.

Morris. D. W. (1986) Proximate and ultimate controls on life-history variation: the evolution of litter size in white-footed mice (Peromyscus leucopus). Evolution 40, 169-81.

Morris, D. W. (1987a) Tests of density-dependent habitat selection in a patchy environment. Ecol. Monogr. 57, 69-81.

Morris, D. W. (1987b). Spatial scale and the cost of density-dependent habitat selection. Evol. Ecol. 1, 379-88.

Morris. D. W. (1988) Habitat-dependent population regulation and community structure. Evol. Ecol. 2.

253-69.

Nicholson, A. J. (1941) The homes and social habits of the wood-mouse (Peromyscus leucopus noveboracensis) in southern Michigan. Amer. Midl. Natur. 25, 196-223.

Norušis. M. J. (1985) Advanced Statistics Guide. SPSS Inc., Chicago, IL, USA.

Ostfeld, R. S., Lidicker. W. Z. Jr and Heske. E. J. (1985) The relationship between habitat heterogencity. space usc, and demography in a population of California voles. Oikos $45,433-42$.

Parker, G. A. and Sutherland, W. J. (1986) Ideal free distributions when individuals differ in competitive ability: phenotype-limited ideal free models. Anim. Behav. 34. 1222-42.

Pimm. S. L. and Rosenzweig. M. L. (1981) Competitors and habitat use. Oikos 37, 1-6.

Pimm, S. L., Rosenzweig. M. L. and Mitchell, W. (1985) Competition and food selection: field tests of a theory. Ecology 66,798-807.

Price, M. V. (19\&4) Microhabitat use in rodent communitics: predator avoidance or foraging economics? Neth. J. Zool. 34, 63-80.

Rhomberg. L. (1984) Inferring habitat selection by aphids from the dispersion of their galls over the tree. Amer. Natur. 124. 751-6.

Rosenzweig. M. L. (1974) On the evolution of habitat selection. Pr. First Int. Congr. Ecol. 401-4.

Rosenzweig. M. L. (1979a) Optimal habitat selection in two-species competitive systems. Fortschr. Zool. 25. $283-93$.

Rosenzweig. M. L. (1979b) Threc probable evolutionary causes for habitat selection. In Contemporary Quantitative Ecology and Related Ecometrics (eds G. P. Patil and M. L. Rosenzwcig). International Cooperative Publishing House, Fairland, MD. USA, pp. 49-60.

Rosenzweig. M. L. (1981) A theory of habitat selection. Ecology 62, 327-35. 
Rosenzweig, M. L. (1986) Some theoretical aspects of habitat selection. In Habitat Selection in Birds (ed. M. L. Cody), Academic Press, London, UK, pp. 517-40.

Rosenzweig, M. L. (1987a) Habitat selection and evolutionary processes. Evol. Ecol. 1, 283-417.

Rosenzweig, M. L. (1987b) Community organization from the point of view of habitat selectors. In Organization of Communities: Past and Present (eds J. H. R. Gec and P. S. Giller), Blackwell Scientific Publications, Oxford, UK, pp. 469-90.

Rosenzweig, M. L. Habitat selection, community organization and small mammal studies. In Patterns in the Structure of Mammalian Communities (eds D. W. Morris et al.), Spccial Publications, The Muscum, Texas Tech University, Lubbock, TX, USA, in press.

Rosenzweig, M. L. and Abramsky, Z. (1985) Detecting density-dependent habitat selection. Amer. Natur. 126, 405-17.

Rosenzweig, M. L., Abramsky, Z. and Brand, S. (1984) Estimating species interactions in heterogeneous environments. Oikos 43, 329-40.

Rowley, M. H. and Christian, J. J. (1976) Intraspecific aggression of Peromyscus leucopus. Behav. Biol. 17, 249-53.

Schoener, T. W. (1974) Resource partitioning in ecological communities. Science 185, 27-39.

Sokal, R. R. and Rohlf, F. J. (1981) Biometry (2nd edn), W. H. Freeman \& Co., San Francisco, CA, USA.

Southwood, T. R. E. (1977) Habitat: the templet for ecological strategies? J. Anim. Ecol. 46, 337-65.

Southwood, T. R. E. (1988) Tactics, strategies and templets. Oikos 52, 3-18.

Stickel, L. F. (1968) Home range and travels. In Biology of Peromyscus (Rodentia) (ed. J. A. King), American Society of Mammalogists, Stillwater, OK, USA, pp. 373-411.

Svärdson, G. (1949) Competition and habitat sclection in birds. Oikos 1, 157-74.

Terman, C. R. (1968) Population dynamics. In Biology of Peromyscus (Rodentia) (ed. J. A. King), American Society of Mammalogists, Stillwater, OK, USA, pp. 412-50.

Toft, C. A. and Shea, P. J. (1983) Detecting community-wide patterns: estimating power strengthens statistical inference. Amer. Natur. 122, 618-25.

Whitham, T. G. (1978) Habitat selection by Pemphigus aphids in response to resource limitation and competition. Ecology 59, 1164-76.

Whitham, T. G. (1980) The theory of habitat selection: examined and extended using Pemphigus aphids. Amer. Natur. 115, 449-66.

Yahner, R. H. (1983) Population dynamics of small mammals in farmstead shelterbelts. J. Mamm. 64, 380-6. 